\title{
Bacteriological Quality Assessment of Raw Beef Sold in Sylhet Sadar
}

\author{
Farhana Jahan $^{1}$, A. T. M. Mahbub-E-Elahi ${ }^{2}$ and A. B. Siddique ${ }^{2}$ \\ ${ }^{1}$ Upazilla Livestock Office, Chandpur Sadar, Chandpur, Bangladesh; ${ }^{2}$ Department of Microbiology \& \\ Hygiene, Sylhet Agricultural University, Bangladesh \\ *Corresponding author and Email: fjrisha@gmail.com
}

Received: 5 May 2014

Accepted: 12 December 2015

\begin{abstract}
This study was conducted to assess the bacteriological quality of fresh raw beef sold in different markets of Sylhet Sadar. A total of seventy five (75) fresh raw beef samples were randomly collected from seven major markets (Shibgonj, Mirabazar, Kazitula, Ambarkhana, Madina market, Bandar bazar and Sheikh ghat) of Sylhet Sadar. Total Viable Count of the samples ranged between $2.5 \times 10^{5}$ to $2.25 \times 10^{8} \mathrm{cfu} / \mathrm{g}$. Acceptability for consumption of these samples as satisfactory, acceptable and rejected were 40,32 and $28 \%$, respectively. A total of 115 bacterial isolates of 5 genera were identified including gram negative Escherichia coli [15(10\%)], Salmonella spp. [20(13.33\%)], Klebsiella spp. [30(20\%)], Enterobacter spp. [10(6.67\%)] and gram positive Staphylococcus spp. [40(26.67\%)]. The presence of these organisms in fresh meat from conventional beef is alarming.
\end{abstract}

Keywords: Total viable count, conventional beef, public health hazard, food borne infection, intoxication

\section{Introduction}

Meat from mature cattle is known as "Beef". Beef is a good source of various nutrients specially protein, fat, phosphorus, enzyme, water etc. Meat is one of the most perishable food and its composition is ideal for the growth of a wide range of spoilage bacteria (Mayr et al., 2003). It also reported that fresh raw meat like beef have been implicated for a number of meat borne infections and intoxications in several countries (Mukhopadhyay et al., 2009). This is because both pathogenic and non-pathogenic organisms live in the gastro-intestinal tract of cattle which can be transferred onto the meat under faulty and poor processing conditions.

Fresh meat becomes contaminated with microorganisms during various processing stages up to consumer uptake. Contaminated raw meat is one of the main sources of food-borne illness (Bhandare et al., 2007). Some of these bacteria may include pathogens. These are the food poisoning microorganisms causing food borne infection and intoxication or spoilage bacteria causing discoloration, bad odors and slime on meat surfaces. If the bacteria on meat include pathogens like E. coli, Salmonella, Staphylococcus etc. there could be a risk to human health. Members of the gram negative bacteria e.g. E. coli are widely distributed in the environment and are the major sources for food contamination. The possible sources of these bacteria are skin of the animal, the equipments used for each operation, clothes and hands of personnel and the physical facilities themselves (Tesfay et al., 2014). It is difficult to set microbiological criteria that would indicate when 
the food risk is unacceptable. This is because of improper sampling.

Another problem is that there are no clear food safety objectives (FSO) for pathogens on fresh meat. An FSO is the maximum level of a food safety hazard in a food that can be considered acceptable for consumer protection. Even if microbiological testing reliably indicates the level of contamination by pathogens (and this may be possible if enough samples are tested) it is difficult to assess the level at which the pathogen is an unacceptable food safety risk. Food safety is better assured through the application of Hazard Analysis Critical Control Point (HACCP) principles and good manufacturing practice (GMP) (FAO Corporate Document Repository, 2007).

Public health is the most uttering concern of today's world. Beef, a delicious food is widely used for public consumption. However, beef processing in most of the city markets is carried out under unhygienic environment and it is important to know the bacteriological quality of those meet for ensuring better food safety. Hence, this study was undertaken to assess the bacteriological quality of raw beef which focuses the very common food poisoning microorganisms causing public health hazard.

\section{Materials and Methods}

\subsection{Sample collection}

Seventy five samples of fresh cattle meat (beef) were randomly purchased from 7 major markets (Shibgonj, Mirabazar, kazitula, Ambarkhana, Madina market, Bandar bazar and Sheikh ghat) of Sylhet Sadar. These were collected from different portions of carcasses. During the study period of October, 2011 to December, 2011, the samples were collected twice from each market. The samples were aseptically collected in different clean polyethylene bags and were transferred immediately to the laboratory for bacteriological quality assessment as described in FAO Corporate Document Repository (2007).

\subsection{Culturing, enumeration and isolation of bacteria}

All the chemicals and reagents used were of analytical grade, obtained from Hi-media Laboratories Pvt. Limited, India. Media used in this study included: Nutrient Agar (NA) and Peptone Water (PW) as general and enriched media. Other media with selective and differential characteristics used were Violet Red Bile Agar (VRBA), Mannitol Salt Agar (MSA), Eosin Methylene Blue (EMB), SalmonellaShigella (SS) Agar, Brilliant Green Agar (BGA), Blood Agar (BA), Mac Conkey Agar (MCA) etc. All media were prepared according to the manufacturer's specification and sterilized at 121 ${ }^{\circ} \mathrm{C}$ and $15 \mathrm{lb}$ pressure for $15 \mathrm{~min}$. Total viable aerobic bacteria count was performed on Nutrient Agar. For this - Meat sample (10 gram meat+ $90 \mathrm{ml}$ sterile distilled water) were homogenized in a sterile blender (first dilution). One $\mathrm{ml}$ from first dilution $\left(10^{1}\right)$ was transferred to second test tube (test tube contains $9 \mathrm{ml}$. of sterile distilled water) ( $2^{\text {nd }}$ dilution or $\left.10^{2}\right)$ so on up to the $6^{\text {th }}$ dilution.

Then, inoculation of sample was done. Inoculation of sample was done by pipetting 1 $\mathrm{ml}$ from $3^{\text {rd }}$ dilution and was transferred to the sterile petridish, also from the $4^{\text {th }}$ dilution to another sterile petridish up to the $6^{\text {th }}$ dilution. The inoculation was followed by the pour plate method, where the sample was first put into the petri dish and $15 \mathrm{ml}$ agar (liquefied in a water bath at $44-46{ }^{\circ} \mathrm{C}$ ) were poured into the plate afterwards. Agar and sample were thoroughly mixed by rotating the petri dish. After that, incubation for 24 hours at $37{ }^{\circ} \mathrm{C}$ and counting of normal plates of 25-250 colonies were carried out. The counts for each plate were expressed as colony forming unit of the suspension ( $\mathrm{cfu} / \mathrm{g}$ ). Discrete colonies were sub cultured into differential and selective media aseptically to obtain pure cultures of the isolates. Pure isolates of the resulting growth were then stored at $4{ }^{\circ} \mathrm{C}$.

\subsection{Identification of bacterial isolates}

Colonies identifiable as discrete on the selective media were carefully examined macroscopically 
for cultural characteristics such as the shape, color, size and consistency. Bacterial isolates were characterized based on microscopic appearance, colonial morphology and Gram's staining reactions as well as appropriate biochemical tests i.e. Lysine Iron Agar (LIA) test, Triple Sugar Iron (TSI) test, Indole production test, Methyl Red (MR) test, VogesProskauer (VP) test, Citrate utilization test, Catalase test and Carbohydrate fermentation test as described by Buxton and Fraser (1977), Cheesbrough (1985) and Carter et al. (1995) were carried out. The isolates were identified by comparing their characteristics with those of known taxa, as described by Bergey's Manual for Determinative Bacteriology (Buchanan and Gribbons, 1974). Data were analysed statistically using the general linear model procedure.

\section{Results and Discussion}

\subsection{Total viable count (TVC)}

To obtain total counts, plates containing well isolated colonies were selected and plates containing overgrowth colonies were avoided. Area basis TVC findings are presented in Table 1. Total Viable Count of collected fresh beef ranged between $2.5 \times 10^{5}$ to $2.25 \times 10^{8} \mathrm{cfu} / \mathrm{g}$. Minimum bacterial load i.e. $2.5 \times 10^{5} \mathrm{cfu} / \mathrm{g}$ was recorded at Kazitula and Bandar bazar. The collected meat samples of Mirabazar area had maximum bacterial load i.e. $2.25 \times 10^{8} \mathrm{cfu} / \mathrm{g}$. Mean microbial count of seven markets ranged between $1.6 \times 10^{7}$ to $4.23 \times 10^{7} \mathrm{cfu} / \mathrm{g}$.

Fresh beef containing organisms less than 0.5 million/gm are considered satisfactory for consumption, more than 0.5 million/gm but less than 2 million/gm are acceptable and more than 2 million/gm are rejected i.e. not good for public consumption (Rahman, 2007). Based on this data, area basis quality percentages of collected meat are presented in Table 2. Overall meat quality percentages based on TVC is illustrated in Figure 1. Beef of Madina market $(50 \%)$, Mirabazar (44.44\%) and Bandar bazar (43.75\%) were of good quality. Raw beef of these markets is satisfactory for public consumption. Total bacterial load into meat of Shibgonj (37.5\%) and Sheikh ghat $(33.33 \%)$ area possess acceptable limit. Meat of these areas is conditionally approved and for this investigation is needed. Meat collected from Ambarkhana (41.67\%) and Kazitula (37.5\%) region is not good for public consumption i.e. rejected. On the basis of microbiological standards of raw beef, $40 \%$ of test samples were satisfactory for consumption, $32 \%$ were acceptable and $28 \%$ were rejected i.e. unacceptable for public consumption.

Fresh meat samples from local markets of Sylhet sadar yielded moderate growth of bacteria. The presence of Escherichia coli, Salmonella spp., Klebsiella spp., Enterobacter spp. and Staphylococcus spp. on meat parts could be attributed to the fact that meat is enriched with all nutrients required for the growth of bacteria in adequate quantity. Then, moderate total viable counts recorded in this study showed the bacterial diversity (differences in forms or species) in these markets, real condition of the market and the hygienic practice employed by meat sellers and butchers. This determined the variation of bacterial contamination.

Table 1. Area basis total viable count obtained from collected fresh beef

\begin{tabular}{llll}
\hline Area & Minimum count $(\mathrm{cfu} / \mathrm{g})$ & Maximum count $(\mathrm{cfu} / \mathrm{g})$ & Mean $(\mathrm{cfu} / \mathrm{g})$ \\
\hline Shibgonj & $2.6 \times 10^{5}$ & $1.15 \times 10^{8}$ & $1.64 \times 10^{7}$ \\
Mirabazar & $2.8 \times 10^{5}$ & $2.25 \times 10^{8}$ & $3.49 \times 10^{7}$ \\
Kazitula & $2.5 \times 10^{5}$ & $1.71 \times 10^{8}$ & $4.23 \times 10^{7}$ \\
Ambarkhana & $3.5 \times 10^{5}$ & $1.2 \times 10^{8}$ & $2.25 \times 10^{7}$ \\
Madina market & $3.7 \times 10^{5}$ & $1.75 \times 10^{7}$ & $3.74 \times 10^{6}$ \\
Bandar bazar & $2.5 \times 10^{5}$ & $8.4 \times 10^{7}$ & $8.6 \times 10^{6}$ \\
Sheikhghat & $3.1 \times 10^{5}$ & $9.7 \times 10^{7}$ & $1.6 \times 10^{7}$ \\
\hline
\end{tabular}




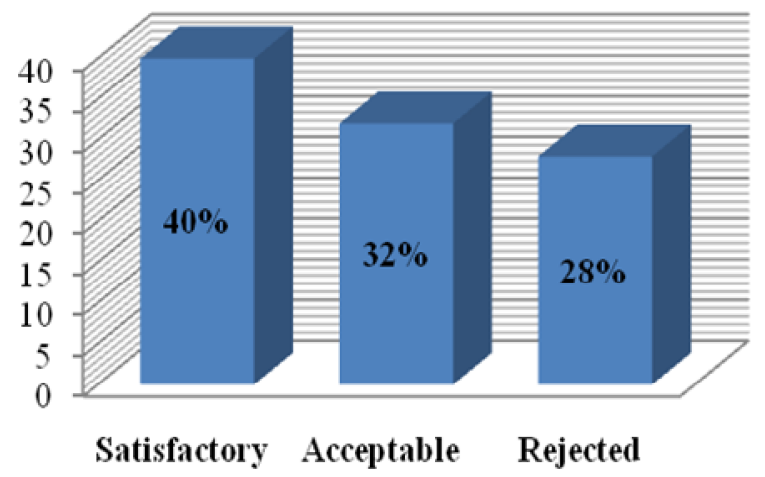

Figure 1. Quality of beef suitable for consumption based on total viable count

Table 2. Area basis meat quality percentage based on total viable count

\begin{tabular}{|c|c|c|c|c|c|c|c|}
\hline \multirow[t]{2}{*}{ Area } & \multirow[t]{2}{*}{$\begin{array}{l}\text { No. of } \\
\text { Sample }\end{array}$} & \multicolumn{2}{|c|}{$\begin{array}{l}\text { Satisfactory/Passed for } \\
\text { Consumption }<.5 \\
\text { million/g) }\end{array}$} & \multicolumn{2}{|c|}{$\begin{array}{l}\text { Acceptable/Conditional } \\
\text { Approval }(>.5 \text { million/g } \\
\&<2 \text { million/g) }\end{array}$} & \multicolumn{2}{|c|}{$\begin{array}{l}\text { Rejected/ } \\
\text { Condemned (>2 } \\
\text { million/g) }\end{array}$} \\
\hline & & No. & Percent & No. & Percent & No. & Percent \\
\hline Shibgonj & 8 & 3 & 37.5 & 3 & 37.5 & 2 & 25 \\
\hline Mirabazar & 9 & 4 & 44.44 & 3 & 33.33 & 2 & 22.22 \\
\hline Kazitula & 8 & 3 & 37.5 & 2 & 25 & 3 & 37.5 \\
\hline Ambarkhana & 12 & 4 & 33.33 & 3 & 25 & 5 & 41.67 \\
\hline Madina market & 10 & 5 & 50 & 3 & 30 & 2 & 20 \\
\hline Bandar bazar & 16 & 7 & 43.75 & 6 & 37.5 & 3 & 18.75 \\
\hline Sheikh ghat & 12 & 4 & 33.33 & 4 & 33.33 & 4 & 33.33 \\
\hline
\end{tabular}

This is an indication of recontamination in food due to handling and hygienic techniques (Clarence et al., 2009). Similar values were reported by Yousuf et al. (2008) and Okonko et al. (2008c, d; 2009 a, b).

\subsection{Isolation and identification}

Characteristic growth of microorganisms into differential media indicated them as E. coli, Salmonella spp., Klebsiella spp., Enterobacter spp. and Staphylococcus spp. Results of these tests are shown in Table 3. A total of 150 isolated colonies from NA agar were inoculated into VRBA and MSA (75 for each). One hundred and fifty colonies of VRBA and MSA were sub-cultured into differential media, performed different biochemical test. Presence of these isolated bacteria is graphically presented in Figure 2.

A total of 115 isolates comprising of 4 different genera of gram negative bacteria and 1 genus of gram positive bacteria were isolated in this study. This showed that different markets contributed equally to the microbial diversity. The bacteria isolates are identified as Escherichia coli, Salmonella spp., Klebsiella spp., Enterobacter spp. and Staphylococcus spp. by comparing their morphological and biochemical characteristics with standard reference organisms (Buchanan and Gribbons, 1974; Cheesbrough, 2003). Microorganisms isolated from fresh meat samples in this study have been earlier found in foods, environment 
and other places and their pattern is similar to previous reports ( Clarence et al., 2009; Okonko et al., 2008 a, b, c, d, 2009).

Agbeyegbe and Uraih (1982) study reported high prevalence rate of Escherichia coli in raw meat samples. Enabulele and Uraih (2009) reported $E$. coli prevalence rate to be $85.65 \%$ in a study with the fresh meat samples from abattoir and traditional open market each, recording $100 \%$ E. coli prevalence. Clarence et al. (2009) reported the presence of $S$. aureus, E. coli, Bacillus spp., Enterobacter, Pseudomonas and Klebsiella in meat pie.

Most of the organisms found in this study are those commonly found in soil and water.
Staphylococcus spp. (26.67\%) was isolated in the present study as reported in all previous work mentioned above. The presence of E. coli $(10 \%)$ and Enterobacter spp. (6.67\%) in this fresh meat samples is an indication of fecal contamination of the meats. This might be due to possible contamination of fresh meats or meat products itself during sales or unhygienic handling of the meats right from slaughtering, butchering plants and processing or due to contamination from the skin, mouth, or nose of the handlers which can be introduced directly into foods by process line workers, with lesions caused by $S$. aureus on hands and arms coming into contact with the food or by coughing and sneezing (Sobukola et al., 2009; Okonko et al., 2008 a, b, c, d and $2009 \mathrm{a}, \mathrm{b})$.

Table 3. Morphological and biochemical characteristics of isolated organisms

\begin{tabular}{|c|c|c|c|c|c|}
\hline \multirow[t]{2}{*}{ Parameters } & \multicolumn{5}{|c|}{ Isolates } \\
\hline & I. & II. & III. & IV. & $\mathrm{V}$. \\
\hline $\begin{array}{l}\text { Gram's } \\
\text { reaction }\end{array}$ & - & - & - & - & + \\
\hline $\begin{array}{l}\text { Cellular } \\
\text { morphology }\end{array}$ & Straight rods & Rods & Rods & Rods & $\begin{array}{l}\text { Round, arranged in } \\
\text { grape like structures }\end{array}$ \\
\hline Motility & + & + & - & + & - \\
\hline Catalase test & + & + & + & - & + \\
\hline Citrate test & - & + & + & - & \\
\hline Indole test & + & - & - & + & - \\
\hline MR test & + & + & - & + & + \\
\hline VP test & - & - & + & - & + \\
\hline $\begin{array}{l}\text { Growth on } \\
\text { TSI }\end{array}$ & $\begin{array}{l}\text { Slant - Red, } \\
\text { Butt - Yellow }\end{array}$ & $\begin{array}{l}\text { Butt - } \\
\text { Black }\end{array}$ & $\begin{array}{l}\text { Butt \& Slant } \\
\text { - Yellow }\end{array}$ & $\begin{array}{l}\text { Gas bubbles in } \\
\text { butt \& medium } \\
\text { frequently split }\end{array}$ & N/A \\
\hline $\begin{array}{l}\text { Growth on } \\
\text { LIA } \\
\text { Sugar } \\
\text { fermentation }\end{array}$ & $\begin{array}{l}\text { Butt \& Slant } \\
- \text { Red }\end{array}$ & $\begin{array}{l}\text { Butt - } \\
\text { Yellow }\end{array}$ & Slant -Red & $\begin{array}{l}\text { Butt \& Slant - } \\
\text { Red }\end{array}$ & N/A \\
\hline Sucrose & $\mathrm{A}$ & $A \& G$ & $\mathrm{~A}$ & $\mathrm{~A}$ & A \\
\hline Glucose & $A \& G$ & $A \& G$ & $A \& G$ & $A \& G$ & A \\
\hline Dextrose & A \& G & $A \& G$ & A \& $G$ & $A \& G$ & A \\
\hline Mannitol & A & A & A & A & A \\
\hline Maltose & A & $A \& G$ & A & $\mathrm{A}$ & A \\
\hline Lactose & A & A \& $\mathrm{G}$ & A & A & A \\
\hline $\begin{array}{l}\text { Isolated } \\
\text { bacteria }\end{array}$ & $\begin{array}{l}\text { Escherichia } \\
\text { coli }\end{array}$ & $\begin{array}{l}\text { Salmonella } \\
\text { spp. }\end{array}$ & $\begin{array}{l}\text { Klebsiella } \\
\text { spp. }\end{array}$ & Enterobacter spp. & Staphylococcus spp. \\
\hline
\end{tabular}




\section{Percentage of organisms}

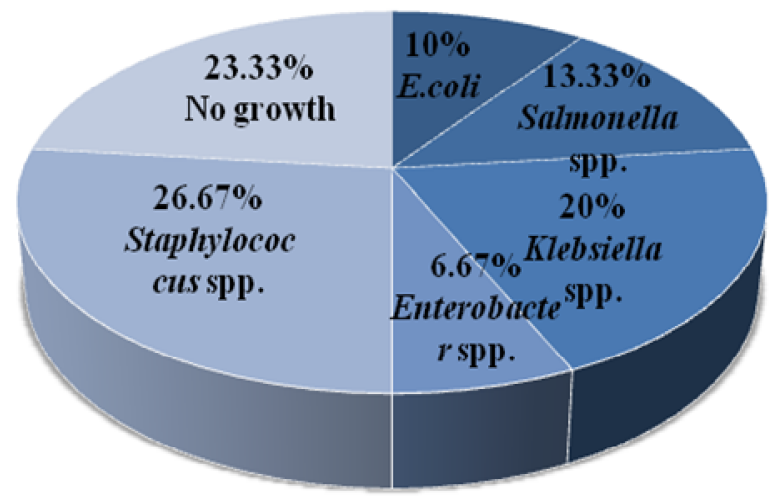

Figure 2. Graphical presentation of different isolated bacteria from the test beef samples

The isolation of Enterobacter spp. may be the result of poor environmental conditions such as dust and contamination of the water used during slaughtering, Enterobacter spp. are also being the inhabitants of dairy products (Talaro and Talaro, 2006). Salmonella spp. (13.33\%), and another organism found in the meats are also a pathogenic organism of public health significance and concerns (Okonko et al., 2009 $\mathrm{a}, \mathrm{b})$. The isolation of Salmonella spp. (13.33\%) in this study is of practical impact. This organism might have contaminated the meats as a result of handling by meat sellers.

\section{Conclusions}

Maximum microbial load of fresh beef was recorded in Mirabazar and minimum load was at Kazitula and Bandar bazar. On the basis of microbiological standards of raw beef, $40 \%$ of test samples were satisfactory for consumption, $32 \%$ were acceptable and $28 \%$ were rejected. Bacteriological quality assessment revealed that both gram positive and gram negative bacteria were common in fresh beef. It may be concluded from the above all findings that microbial load of fresh beef was in acceptable limit. Hence, isolated organisms have public health significance i.e. they are responsible for various food borne infection and intoxication. Precautionary management is therefore, deemed necessary.

\section{References}

Agbeyegbe, J. M., Uraih, N. 1982. The prevalence of E. coli in meat samples in Benin City, Nigeria. Microbios Letters, 20: 21-28.

Bhandare, S. G., Sherikarv, A. T., Paturkar, A. M, Waskar, V. S., Zende, R. J. 2007. A comparison of microbial contamination of sheep/goat carcassses in a modern Indian abattoir and traditional meat shops. Food Control, 18: 854-868.

Buchanan, R. E., Gribbons, N. E. 1974. Bergey's Manual of Determinative Bacteriology (8th edition). Williams \& Wilkins Co. Baltimore, USA.

Buxton, A. and Fraser, G. 1977. Animal Microbiology. Blackwell Scientific Publications, Oxford, London, Edinburgh, Melbourne, Vol. 1, 85-86 pp. 
Carter, G. R., John, R. Cole, Jr. 1995. Diagnostic Procedures in Veterinary Bacteriology \& Mycology. $6^{\text {th }}$ Edition, 551-556 pp.

Cheesbrough, M. 1985. Medical laboratory manual for tropical countries. Vol. 2. Microbiology, 400-480 pp.

Cheesbrough, M. Medical Laboratory Manual. (2003). Tropical Health Technology, Low priced Edition. Doddington, Cambridgeshire, England, 20-35 pp.

Clarence, S. Y., Obinna, C. N., Shalom, N. C. 2009. Assessment of bacteriological quality of ready to eat food (Meat pie) in Benin City metropolis, Nigeria. African Journal of Microbiology Research, 3(6): 390-395.

Enabulele, S. A., Uraih, N. 2009. Enterohemorrhagic Escherichia coli 0157:H7 Prevalence in meat and vegetables sold in Benin City, Nigeria. African Journal of Microbiology Research, 3(5): 276-279.

FAO. 2007. Meat processing technology for small- to medium-scale producers by FAO Corporate Document Repository.

Mayr, D; Margesin, R., Klingsbichel, E., Hartungen, E., D. Jenewein, D., Schinner, F. and Ma rk1, T. D. 2003. Rapid Detection of Meat Spoilage by Measuring Volatile Organic Compounds by Using Proton Transfer Reaction Mass Spectrometry. Applied Environmental Microbiology, 69:4697-4705.

Mukhopadhyay, H. K., Pillai, R. M., Pal, U. K. and Ajay Kumar, V. J. 2009. Microbial quality of fresh chevon and beef in retail outlets of Pondicherry Tamilnadu. Journal of Veterinary and Animal Sciences, 5 (1): 33-36.

Okonko, I. O., Adejoye, O. D., Ogunnusi, T. A., Fajobi, E. A., Shittu, O. B. 2008a. Microbiological and physicochemical analysis of different water samples used for domestic purposes in Abeokuta and
Ojota, Lagos State, Nigeria. African Journal of Biotechnology, 7(3): 617-621.

Okonko, I. O., Ogunjobi, A. A., Fajobi, E. A., Onoja, B. A., Babalola, E. T., Adedeji, A. O. 2008b. Comparative studies and microbial risk assessment of different Ready-to-Eat (RTE) frozen sea-foods processed in Ijora-olopa, Lagos State, Nigeria. African Journal Biotechnology, 7(16): 2898-2901.

Okonko, I. O., Ogunjobi, A. A., Adejoye, O. D., Ogunnusi, T. A., Olasogba, M. C. 2008c. Comparative studies and Microbial risk assessment of different water samples used for processing frozen sea-foods in Ijoraolopa, Lagos State, Nigeria. African Journal of Biotechnology, 7(16): 29022907.

Okonko, I. O., Ogunnusi, T. A., Ogunjobi, A. A., Adedeji, A. O., Adejoye, O. D., Babalola, E. T., Ogun, A. A. 2008d. Microbial studies on frozen shrimps processed in Ibadan and Lagos, Nigeria. Scientific Research and Essay, 3(11): 537-546.

Okonko, I. O., Ogun, A. A., Adejoye, O. D., Ogunjobi, A. A., Nkang, A. O., AdebayoTayo, B. C. 2009a. Hazards analysis critical control points (HACCP) and Microbiology qualities of Sea-foods as affected by Handler's Hygiene in Ibadan and Lagos, Nigeria. African Journal of Food Science, 3(1): 035-050.

Okonko, I. O., Donbraye, E., Babatunde, S. O. I. 2009b. Microbiological Quality of Seafood processors and water used in two different sea processing plants in Nigeria. Electronic Journal of Environmental, Agricultural and Food Chemistry, 8(8): 621-629.

Rahman, M. M., 2007. Meat Hygiene \& Technology, 54-286 pp.

Sobukola, O. P., Awonorin, O. S., Idowu, A. M., Bamiro, O. F. 2009. Microbial profile and critical control points during processing of 
'robo' snack from melon seed (Citrullus lunatus thumb) in Abeokuta, Nigeria. African Journal of Biotechnology, 8(10): 2385-2388.

Talaro, K., Talaro, A. 2006. Foundation in Microbiology. W.M.C Brown publisher, Dubuque, $781-783$ pp.

Tesfay, K., Berihun, A., Habtamu, T., Abrha, B. 2014. Assessment of Bacteriological
Quality of Sold Meat in the Butcher Shops of Adigrat, Tigray, Ethiopia. Applied Journal of Hygiene, 3 (3): 38-44.

Yousuf, A., Ahmed, M. K., Yeasmin, S., Ahsan, N., Rahman, M. M., Islam, M. M. 2008. Prevalence of Microbial Load in Shrimp, Penaeus monodon and Prawn, Macrobrachium rosenbergii from Bangladesh. World Journal of Agricultural Science, 4 (S): 852-855. 